\title{
STILL THE SAME HAWK
}


This page intentionally left blank 


\section{STIL THE SAME HAWK Reflections on Nature and New York}

\section{Edited by \\ JOHN WALDMAN}

Empire State Editions

An imprint of Fordham University Press

ESE New York 2013 
Copyright (C) 2013 John Waldman

"Public Place, Brooklyn" (C) 2013 Kelly McMasters

All rights reserved. No part of this publication may be reproduced, stored in a retrieval system, or transmitted in any form or by any means-electronic, mechanical, photocopy, recording, or any other-except for brief quotations in printed reviews, without the prior permission of the publisher.

Fordham University Press has no responsibility for the persistence or accuracy of URLs for external or third-party Internet websites referred to in this publication and does not guarantee that any content on such websites is, or will remain, accurate or appropriate.

Fordham University Press also publishes its books in a variety of electronic formats. Some content that appears in print may not be available in electronic books.

Library of Congress Cataloging-in-Publication Data is available from the publisher.

Printed in the United States of America

$\begin{array}{llllllll}15 & 14 & 13 & 5 & 4 & 3 & 2 & 1\end{array}$

First edition 